\title{
Anthropogenic aerosols may have increased upper tropospheric humidity in the 20th century
}

\author{
M. Bister and M. Kulmala \\ Department of Physics, University of Helsinki, Helsinki, Finland \\ Received: 20 August 2010 - Published in Atmos. Chem. Phys. Discuss.: 11 October 2010 \\ Revised: 13 April 2011 - Accepted: 14 April 2011 - Published: 13 May 2011
}

\begin{abstract}
Recent simulations of deep convection with a spectral microphysics cloud model show that an increase in aerosol concentration can have a significant effect on the nature of convection with more ice precipitation and less warm rain in polluted air. The cloud lifetime and the area covered by cloud anvils of deep convection are also larger for polluted air. Therefore, it is possible that the increase of anthropogenic aerosols in most of the 20th century has increased humidity and perhaps also cloudiness in the mid- to upper troposphere. Satellite data of upper tropospheric relative humidity in 1979-1997 and observed changes in cloudiness support this hypothesis. As changes in upper tropospheric humidity strongly affect longwave radiation, it is possible that anthropogenic aerosols have had a significant warming effect in addition to their other known effects on radiation.
\end{abstract}

\section{Introduction}

Climate sensitivity to the doubling of atmospheric $\mathrm{CO}_{2}$ strongly depends on feedbacks associated with water vapor and clouds. An estimate of the sensitivity can be pursued by studying the physical processes themselves or by constraining the sensitivity with observations. In the latter method, it is crucial to account for all possible changes in the Earth's atmosphere that may have affected the temperature record. One important example is changes in the amount of anthropogenic aerosols. The more aerosols and their effects have been studied, the more complicated role they seem to have in the behavior of the atmosphere. It is well known that they affect radiation, not only directly but also through various interactions in the microphysics of clouds and precipitation.

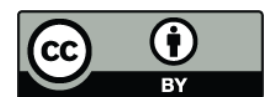

Correspondence to: $\mathrm{M}$. Bister (marja.bister@helsinki.fi)
Also, some of their effects are far from linear. For example, aerosols' effect on precipitation can be even qualitatively different in pristine and polluted environments (Rosenfeld et al., 2008; Wild, 2009). Complicated as their role may be, aerosols are of first order importance to the climate variations associated with anthropogenic changes in the composition of the atmosphere. Therefore, it is an intriguing question whether aerosols have yet another, so far overlooked effect on the Earth's atmosphere.

In this paper, we draw attention to an effect that was pointed out by Ramanathan et al. (2001). As they stated, "Suppression of precipitation in the updrafts of very deep clouds, especially in the tropics, can also transport more water and aerosols into the upper troposphere and the lower stratosphere. The accompanying increase in the upper troposphere water vapor greenhouse effect can counter some of the aerosol cooling effect". In a steady state, however, the total amount of precipitation is constrained by energy balances. Changes in microphysics can, however, affect humidity even in the absence of changes in the total amount of precipitation, as will be argued in Sect. 5 .

As a first attempt to approach this problem we ask the following questions in the similarly numbered sections of this work: (2) What is the mechanism of a possible humidity increase associated with aerosols? (3) Do observations support changes in the upper tropospheric humidity due to known trends in the amount of anthropogenic and other aerosols? We use sulfate aerosols as a proxy for pollution aerosols and also discuss changes in desert dust and smoke from biomass burning. (4) Do observations show changes in cloudiness or other quantities that could be associated with the suggested humidity increase? (5) It has been shown in many studies that, to the first order, humidity in the free troposphere can be simulated without explicitly accounting for the microphysics in clouds. Does that mean that changes in the microphysics associated with changes in the amount of aerosols cannot

Published by Copernicus Publications on behalf of the European Geosciences Union. 
affect tropospheric humidity? We argue that this is not the case. (6) How large an effect could a few percent increase in upper tropospheric relative humidity have on radiation?

Due to the potential importance of this topic to sensitivity studies, we feel that a qualitative approach is justified as a first step to understand what the issues are. We hope that this paper encourages research on the effect of changes in microphysics on tropospheric humidity, and especially in the upper troposphere.

\section{What is the mechanism of humidity increase associated with aerosols?}

Khain et al. (2005 and 2008) studied the effect of aerosols on the development of deep convective clouds with freezing level in the midtroposphere (about $4 \mathrm{~km}$ altitude) using a spectral microphysics cloud model. Their simulations showed more ice particles in the upper troposphere in polluted air than in clean air. The ice particles in polluted air fell slowly from higher levels and often far from the cloud updrafts and sublimated as they fell. The lifetime of clouds in a polluted atmosphere was also longer, which the authors attributed to the existence of a large quantity of ice crystals and small graupel with a long residential time. On the contrary, rain in clean air formed at lower levels and fell down through the cloud updrafts or in the close vicinity of them and there was a smaller hydrometeor mass left in the air aloft than in polluted clouds. Note that the more ice there is in the upper troposphere, the larger the potential for sublimation is, whether it is associated with sedimentation of ice, mixing of air, or some other process. Khain et al. (2005) showed that an increase in aerosol amount was also associated with an increased level of the heating peak associated with the latent heat release. An increase in the area covered by upper tropospheric cloud was also noted for polluted air. These differences are summarized schematically in Fig. 1.

Over two thirds of precipitation on Earth occurs within the Tropics (Hong et al., 1999), where the freezing level lies in the midtroposphere, as in the cloud model simulations of Khain et al. In midlatitudes, the freezing level is also close to that altitude most of the year. Therefore, the result of aerosols enhancing the formation of upper tropospheric ice clouds possibly applies to a large fraction of precipitation on Earth. Note that as no general circulation model (GCM) explicitly parameterizes aerosol effects on convective clouds (Quaas et al., 2009), this effect cannot be seen in GCM results.

In Sect. 5, we will further discuss whether changes in the microphysics of convective clouds can cause changes in upper tropospheric humidity. We note that such an effect has been seen in a simulation of radiative-convective equilibrium of an aquaplanet with a constant sea surface temperature, using a two-dimensional cloud-resolving convection parameterization (Grabowski, 2003). With prescribed radiation, up-

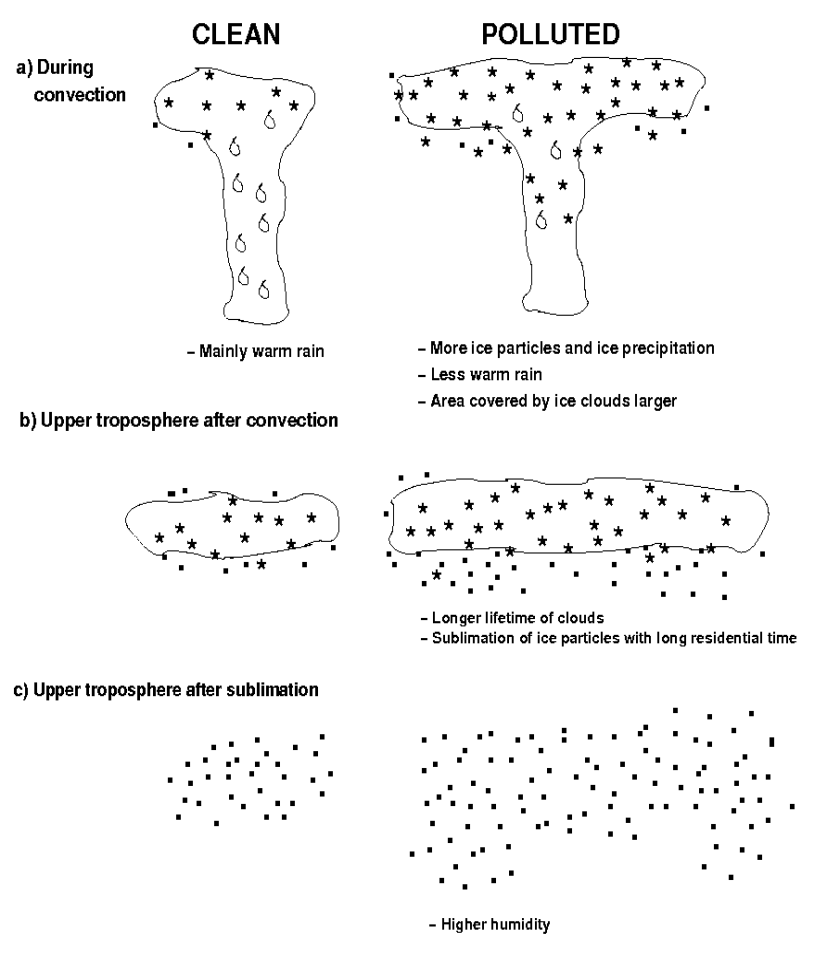

Fig. 1. Differences in deep convection in clean and polluted air schematically. Differences in (a) and (b) are based on cloud model simulation results by Khain et al. $(2005,2008)$ and are supported by observational studies of Zhang et al. (2007) and Koren et al. (2005), who found increased upper level cloudiness associated with an increased amount of pollution (see Sect. 4). We suggest that higher upper tropospheric humidity in polluted air is a result of convection (as in c). Observational studies of Udelhofen and Hartmann (1995, see Sect. 4) as well as Soden (2004, see Sect. 5) support higher humidity associated with larger ice anvils.

per tropospheric relative humidity (UTRH) was about $10 \%$ higher in the simulation with small cloud and precipitation particles than in the simulation with large cloud and precipitation particles. With interactive radiation, the difference was much smaller. The microphysics scheme, however, considered just two classes of condensed water, cloud water and rain with a threshold temperature for the transition between liquid and solid. Also, in the scheme there was no distinction between latent heating of condensation and deposition. These simplifying choices may have had some effect on the simulation of UTRH.

\section{Do observations suggest changes in the upper tropospheric relative humidity due to changes in the amount of anthropogenic aerosols?}

There are many natural and also anthropogenic sources of aerosols. We use sulfate aerosols as a proxy for pollution aerosols. This is because sulfate aerosols are a key 
component when changes in anthropogenic aerosols in the 20th century are considered. Also, Streets et al. (2006) showed that trends of $\mathrm{SO}_{2}$ and black carbon are qualitatively similar globally. It has been suggested that changes in their trends may be the cause of reduction of aerosol optical depth over world oceans (Wild, 2009). We also consider aerosols from biomass burning and desert dust.

Recent estimates of the global sulfur emissions show a large increase in the 20th century. Sulfur emissions increased globally from about $10 \mathrm{Tg} \mathrm{S}$ in 1900 to about $25 \mathrm{Tg} \mathrm{S}$ in 1940 and to about $70 \mathrm{TgS}$ in 1980 (Stern, 2006). In the 1980s, many studies show a leveling off of emissions with a fairly rapid decline occurring in the 1990s (Smith et al., 2004; Stern, 2006; Streets et al., 2006). As the amount of sulfate aerosols in the troposphere depends directly on sulfur emission, the effect of sulfate aerosols' forcing on the climate is also expected to adjust quickly to changes in sulfur emission.

Khain and Pokrovsky (2004) noted that the main aerosol effect on deep convective clouds in their model simulations came from aerosols penetrating the cloud base. In other words, aerosols in the boundary layer were more important than aerosols in the free troposphere. However, they simulated a deep and wide convective cloud. For other types of clouds, especially narrower convective clouds, free tropospheric aerosols may be more important.

Fridlind et al. (2004) showed evidence that subtropical anvil cloud nuclei are dominated by midtropospheric aerosols. They note that longe-range transport can therefore dominate the effect of local sources of pollution on subtropical anvil clouds.

Satellite data which have been available since 1979 do not reveal a systematic global-scale change in the UTRH between 1979 and 1997 (Bates and Jackson, 2001; McCarthy and Toumi, 2004). Also, Soden et al. (2005) showed that the behavior of global upper tropospheric humidity in the period 1982-2004 can be much better approximated by the assumption of constant relative humidity than the assumption of no moistening at all. The absence of any significant trend in UTRH is not surprising as the trend of sulfur emissions has been estimated to be small in the 1980s and it has been clearly negative only since the 1990s. Regarding the global changes in relative humidity, it is very unfortunate that there is reliable data on upper tropospheric humidity only after the largest change in sulfur emissions had already taken place between the 1940s and the 1970s. Current understanding of the magnitude of problems related to humidity measurements at cold temperatures with radiosonde sensors (Elliott and Gaffen, 1991; John and Buehler, 2005) discourages using them for global trend studies, even though local trends have been obtained with radiosonde data (Treffeissen et al., 2007). It may therefore be impossible to obtain reliable global relative humidity data from the period when sulfur emissions increased most.

When it comes to local trends of UTRH and whether those can be associated with trends in the anthropogenic aerosols, a few facts have to be taken into account. First, aerosols' effect on microphysics is not linear. The effect of increasing the amount of aerosols in pristine and polluted atmosphere can be very different as stressed by Wild in his review of global dimming and brightening (2009; see also Ekman et al., 2007). Second, recent research suggests that anthropogenic pollution sources affect aerosol levels on a large, even global, scale (Kishcha et al., 2007 and other references in Wild, 2009). Third, the suggested aerosol effect on local UTRH depends on the existence of convection. Fourth, the local effects of aerosols depend also on the wind field which advects the aerosols.

McCarthy and Toumi (2004) analysed relative humidity fields from the High-Resolution Infrared Radiation Sounder (HIRS). Their data shows an increase of UTRH in the tropics from 1979 to 1997 and a decrease in both Northern (NH) and Southern Hemisphere ( $\mathrm{SH})$ subtropics and higher latitudes, except north of $40^{\circ} \mathrm{N}$. These changes are shown schematically in Fig. 2. If Stern's (2006) estimate is correct, on the global level there was a decreasing trend in sulfur emissions in 1979-1997. On the other hand, in Asia, sulfur emissions increased during most of this period (Stern, 2006; Streets et al., 2006). A rather large increase also occurred in South Asia from 1980 to 2000 (Streets et al., 2006). We suggest that part of the general decrease of UTRH in subtropics and middle latitudes could have its root in the decrease of global sulfur emissions (Fig. 2). However, changes in UTRH are rather small in the close vicinity of Asia. The absence of changes of UTRH in (South) Asia may be due to the saturation of cloud microphysics effects with high concentration of pollution. Large changes in UTRH have occurred in other tropical regions as we will discuss below.

Two other major sources of aerosols in the atmosphere in addition to anthropogenic air pollution are desert dust and smoke from biomass burning (Rosenfeld et al., 2001). Biomass burning leads to large quantities of small cloud condensation nuclei that can suppress precipitation. Rosenfeld et al. (2001) have shown evidence that also desert dust from the Sahara (and Sahel regions, see Nicholson, 2000) suppresses precipitation. Therefore, changes in the amount of those aerosols have to be taken into account in trying to pin down a possible link between UTRH and changes in the number of cloud condensation nuclei $(\mathrm{CCN})$. Note that in McCarthy and Toumi's analysis, the largest local increase of UTRH has occurred interestingly in the vicinity of equatorial Africa and also over equatorial South America (their Fig. 5). Elsewhere in the tropics, the increase has been much smaller. There have been no large changes in sulfur emissions in these regions, but changes in the other main sources of aerosols have occurred there. West Africa is the source of almost half of the mineral aerosols in the atmosphere (Andreae, 1995). Nicholson (2000 and references therein) show that in the 1980s there was a strong negative anomaly in the rainfall in the Sahel region of West Africa, which is the source of most of the desert dust. In the 1980s, the frequency of dust over 


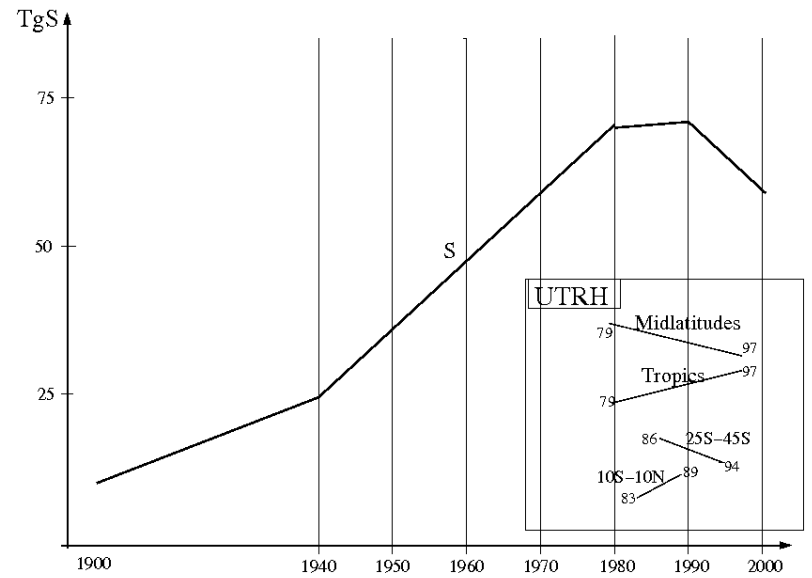

Fig. 2. A schematic representation of global emissions of sulfur from Stern (2006) and UTRH changes from McCarthy and Toumi (2004) in midlatitudes, tropics, and two different latitude bands. UTRH has decreased everywhere except in the tropics and north of $40^{\circ} \mathrm{N}$ in 1979-1997. It is argued that this decrease may be related to the global decrease of sulfur emissions. The particularly strong increase of UTRH in the tropics in 1983-1989 may be associated with high desert dust levels and the increase in biomass burning in South America. See text for details.

West Africa and dust concentrations in more distant regions (e.g. Barbados) were remarkably higher than in the two earlier decades.

Mahowald et al. (2007) analyzed visibility data from meteorological stations in dusty regions to assess the anthropogenic impact on desert dust emissions. Their data suggest a peak in desert dust emissions in 1985 both in West Sahel and in North Africa on the whole. The visibility was also worse in 1997 than in 1979 in West Sahel.

There are large uncertainties in the estimates of historical trends of biomass burning. Still, biomass burning emissions seem to have increased rapidly since the 1980s (Mieville et al., 2010). Prins and Menzel (1994) noted increasing trends in South American biomass burning from 1983 to 1991 by analyzing 2-week long periods at the peak of the burning seasons. The analysis of biomass burning emissions of Duncan et al. (2003) also shows a clear increase in the monthly regional aerosol index from the Total Ozone Mapping Spectrometer over Brazil from 1983 to 1989 (see their Fig. 8). The increasing trend continued in the late 1990s. Koren et al. (2007) found an increase in biomass burning in the Amazon from 1998 to 2005, with a reversal of the trend in 2006.

We suggest that the particularly large positive trends of UTRH in the vicinity of equatorial Africa and South America during 1979-1997 in the analysis of McCarthy and Toumi may be related to the aforementioned changes in biomass burning and desert dust. Further support for this interpretation comes from their analysis of the trend for the latitude band of $10^{\circ} \mathrm{S}-10^{\circ} \mathrm{N}$, which is schematically reproduced in
Fig. 2. Most of the increase in UTRH in this latitude band actually took place in 1983-1989, which was the time of both the increase in biomass burning in South America and an increased source of desert dust over North Africa with a peak in the latter in 1985 and high values still in 1989 (Mahowald et al., 2007).

For the latitude band $25^{\circ} \mathrm{S}-45^{\circ} \mathrm{S}$, most of the decrease in UTRH during the $18 \mathrm{yr}$ of the analysis by McCarthy and Toumi occurred in 1986-1994 (again schematically shown in Fig. 2). We suggest that the decrease in this latitude band as well as the somewhat smaller decrease in parts of the $\mathrm{NH}$ midlatitudes could be due to the general decrease of global sulfur emissions. It is interesting that the largest decrease of UTRH occurs in the SH whereas the largest decrease of sulfur emissions has occurred in the $\mathrm{NH}$. As the sulfur emissions are about ten times larger in the $\mathrm{NH}$ than in the $\mathrm{SH}$ and as aerosols due to air pollution may be hemispherically dispersed (Wild, 2009 and references therein, Mishchenko et al., 2007), it would not be surprising if the long-term aerosol trends in the $\mathrm{SH}$ reflected changes in the $\mathrm{NH}$ emissions. One explanation for the larger decrease of UTRH in the SH than in the $\mathrm{NH}$ could be the logarithmic sensitivity of clouds to CCN (Koren et al., 2008 and references therein). Therefore in pristine environments (which the $\mathrm{SH}$ is compared to the $\mathrm{NH}$ ), small changes in $\mathrm{CCN}$ have a much larger effect on cloud properties than in polluted environments.

Clearly, a more thorough analysis is needed to understand why there seems to be a smaller decrease of UTRH in the $\mathrm{NH}$ than in the SH. The main sources of aerosols, their different characteristics of transport, and effects on cloud microphysics should be taken into account in such an analysis. It is also possible that the larger decrease of UTRH in the SH could be due to unknown changes in atmospheric dynamics.

Interestingly, the third region where UTRH has increased in 1979-1997 is over the boreal regions of Asia (Fig. 5 in McCarthy and Toumi). We wonder if this increase could be related to possible changes in biomass burning in this region. Whatever the reason is, even if it is due to errors in the data, it has some effect on the smaller decrease of UTRH in the $\mathrm{NH}$ midlatitudes as compared to the SH midlatitudes.

Changes in the atmospheric circulation patterns may affect UTRH as well. For example, the North Atlantic Oscillation (NAO) index has had a positive anomaly in most of the 1980s and 1990s. A positive anomaly in the NAO index is associated with wet winters in Northern Europe. However, the region most affected by NAO shows rather small changes in UTRH in the analysis of McCarthy and Toumi.

Bates et al. (2001) studied the relationship between upper tropospheric humidity from HIRS and dynamical states in the subtropical regions. They found that the largest contribution to the interannual anomaly time series of the upper tropospheric humidity in 1979-1998 came from the eastern Pacific. They noted that, in certain conditions, Rossby waves can propagate deep into the subtropics. Such a situation is associated with a moistening of the normally dry 
subtropics, particularly in the eastern Pacific. However, the trend of UTRH in McCarthy and Toumi (their Fig. 5) lacks a significant contribution from the eastern Pacific, suggesting that propagation of Rossby waves cannot explain the trend in UTRH in 1979-1997.

Different observations show that the Hadley cell has widened by $2-5$ degrees since 1979 (Seidel et al., 2008). This widening can also be seen in climate models (Johanson and $\mathrm{Fu}, 2009$ ). It is possible that the Hadley cell widening affects also upper tropospheric humidity. However, there is no clear signal of such an effect in the UTRH data. Although there is a decrease of UTRH in the subtropical regions (Fig. 5 of McCarthy and Toumi, 2004), this decrease is not restricted to the region of subsidence associated with the Hadley cell. This could be due to water vapor transport (e.g. Knippertz and Wernli, 2010; Cau et al., 2007). However, the UTRH trend does not show a corresponding large region of increasing humidity, which should exist if the subsidence region of the Hadley cell has shifted poleward. Moreover, the decrease in the SH subtropics and the (local) increases in the tropics did not occur simultaneously (Fig. 2).

Other possible dynamical shifts should also show up as both positive and negative anomalies in relative humidity. It is interesting that such anomalies cannot be seen in the analysis of McCarthy and Toumi.

Johnson and Xie (2010) show that the convectively active fractional area in the tropics is likely to be conserved in a warming climate; however, the location of convection can change as a response to changes in the location of SST exceeding the threshold for convection. An example of changes in the location of convection on a shorter time scale is the dipole mode of SST in the tropical Indian Ocean (Saji et al., 1999). In principle, this mode can affect UTRH in the West Indian Ocean and around Indonesia. However, there is no change in UTRH in the region of Indonesia in the analysis of McCarthy and Toumi. Moreover, the increase of UTRH in the tropics occurred mainly in 1983-1989 (Fig. 2). During this time interval, the changes in the dipole mode of the Indian Ocean were quite weak.

Another important large-scale circulation change that can affect UTRH is El Nino and the Southern Oscillation (ENSO). To minimize ENSO's effect, certain months (and years, in a separate checkup) were excluded in the data analysis of McCarthy and Toumi. They conclude that ENSO cannot explain the observed trends in UTRH. It is also notable that there are no large changes in UTRH in regions most affected by ENSO.

A weakening of tropical circulation, both Walker and Hadley circulation, is suggested by recent studies (e.g., Vecchi et al., 2006; Lu et al., 2007). A weakening of tropical circulations with a slight increase of precipitation is also expected to occur with the warming of the climate by simple reasoning (e.g. Knutson and Manabe, 1995; Vecchi et al., 2006; Held and Soden, 2006). The possible net effect on UTRH from these changes is not known. However, as
McCarthy and Toumi note, changes in the hydrological cycle, or overturning circulation, cannot be the reason for the UTRH changes as the (rather local) increase of UTRH in the tropics and the decrease in the SH subtropics did not occur simultaneously (Fig. 2). McCarthy and Toumi conclude that some other decadal-scale ocean-atmosphere variability or sensitivity to intersatellite calibration may be the reason for the observed trends in UTRH.

While many extratropical stations have shown a reversal of dimming to brightening during the 1980s (see also Sect. 4), there is some suggestion of ongoing dimming in the tropics, although it cannot be verified due to the lack of reliable longterm observations there (Wild, 2009). Lately, Kishscha et al. (2007) found that aerosol optical depth (AOD) increased in the tropics and decreased in the subtropics and middle latitudes of both hemispheres in 2000-2006. It is interesting that these latitudinal bands with different signs of inferred aerosol trends are roughly the same as the latitudinal bands with different signs of trends of UTRH in 1979-1997 (McCarthy and Toumi, 2004).

\section{Do observations show changes in upper tropospheric cloudiness or other quantities that may be related to upper tropospheric relative humidity?}

If aerosols affect the amount of upper tropospheric ice particles generated in deep convection as in the simulations of Khain et al. (2005, 2008), a decrease of upper tropospheric cloudiness could be one observable result of a decrease in anthropogenic aerosols. The simulations of Ekman et al. (2007) of a deep convective cloud with a cloud-resolving model including an explicit aerosol model suggests that the concentration of ice nuclei may be important for the size of the anvil cloud. With regard to the concentration of ice nuclei, estimates of global black carbon emissions show a peak in the 1980s and a decrease thereafter (Streets et al., 2006). Therefore, the trends of sulfur and black carbon emissions are similar although not identical.

Interestingly, there is some consistency between different satellite and surface observations of a reduction in high cloud cover during the 1990s relative to the 1980s (Trenberth et al., 2007). If global sulfur emissions leveled off in the 1980s and decreased rapidly in the 1990s as discussed in Sect. 2, the changes in the upper tropospheric cloud amounts are qualitatively what we would expect due to these changes in emissions.

Koren et al. (2005) evaluated the aerosol effect on clouds using large statistics of satellite data over the North Atlantic Ocean. They found that polluted clouds developed more extensive ice anvil clouds than clean clouds. This result remained the same when meteorological effects on the cloudiness were accounted for by analyzing the data separately for different vertical wind categories. A similar effect of pollution on high clouds was also suggested by the study of 
Zhang et al. (2007). They found a trend of increasing wintertime deep convective clouds and high clouds over the Pacific Ocean from satellite cloud measurements from 1984-2005. They suggested that an increasing amount of aerosols from the Asian pollution outflow was the reason for the increases in the cloud amounts.

May et al. (2009) analysed 44 cases of storms north of Darwin to study how aerosols affect them. Their results were not consistent with those of Koren et al. (2005). However, the observed systematic variation of moisture between the high and low aerosols cases, as well as other possible differences in the convective environment, may have affected this result.

Udelhofen and Hartmann (1995) studied the effect of tropical cloud systems on the UTRH. In their analysis, UTRH increased linearly with the amount of upper level cloud. Soden (2004) also found a positive relation between upper tropospheric cloudinesss and downstream humidity in a convective event (see Sect. 5). These observational studies together suggest that increased pollution leads to more extensive ice anvil clouds and that increased upper level cloudiness is associated with increased UTRH.

In addition, the timing of dimming in 1960-1990 and brightening in many locations after 1990 suggests that changes in aerosol amount and perhaps also clouds may be the main reason for such changes in the surface short-wave radiation (Wild, 2009). For example, increases of cloudiness have been reported over many continental regions while there was dimming. However, it is not yet clear how much of the dimming is due to changes in clouds.

\section{Can we expect changes in microphysics to have an ef- fect on upper tropospheric humidity?}

Possible changes in the humidity profile of the extensive subsiding regions of the subtropics could have a large effect on the nature of the water vapor feedback (e.g. Pierrehumbert and Roca, 1998). It has been argued that this humidity is governed by poorly understood microphysics. On the other hand, it has been suggested that the subtropical humidity can be predicted to first order if the large-scale wind and temperature fields are known and that information about water condensate in the clouds is less important (e.g., Salathe and Hartmann, 1997; Dessler and Sherwood, 2000). (For a review of the latter theory, see Sherwood et al., 2010.) However, the assumption of no delay in the occurrence of precipitation (Dessler and Sherwood, 2000) and the depth of the horizontal outflow from convection (Salathe and Hartmann, 1997) were found to be important for the correct simulation of humidity. In addition, Soden (2004) found that the maximum extent of cirrus anvil coverage during the lifecycle of a convective event was associated with a higher downstream humidity level following the anvil's dissipation. His analysis suggested that this moistening effect was not attributable to the evaporation of cirrus condensate but instead was due to more vapor detrainment being associated with larger cirrus anvil coverage.

Dessler and Minschwaner (2007) used a trajectory-based large-scale control (LSC) model to investigate the regulation of tropospheric humidity. They conclude that the good agreement between the model and the measurements supports the idea that detailed microphysics need not be included to accurately simulate water vapor. In their model, using a non-zero sedimentation time for ice degrades the simulated humidity field. This result must, however, depend on the value of the parameter used for condensation. Dessler and Minschwaner used a relative humidity threshold of $100 \%$ for condensation. To account for subgrid-scale processes, a lower value could be chosen for this parameter. In that case, the correct simulation of water vapor could well require a non-zero sedimentation time for ice. Such a result would support the important role of microphysics, particularly the transport and sublimation of ice.

The moistening potential associated with transported ice was shown with the same LSC model by using a timescale of one day for the sedimentation of ice. The amount of water vapor in the upper troposphere more than doubled when this timescale was used.

Folkins et al. (2002) showed that the relative humidity between 11 and $14 \mathrm{~km}$ in the tropics is determined by the deep convection detrainment profile, the temperature profile and the height of zero radiative heating. However, they suggest that below this layer, the sublimation of ice and the evaporation of water could be important in increasing the relative humidity of unsaturated air.

As a conclusion, changes in upper tropospheric humidity due to changes in the microphysics of clouds cannot be ruled out based on the idealized studies discussed above, even if the simple models would be successful in predicting the crude features of the humidity field correctly. Recent studies by Wright et al. (2009a, b) suggest a direct effect of microphysics on the humidity. Wright et al. (2009a) showed that larger amounts of detrained ice in convection were associated with enhanced upper tropospheric moistening. Moreover, Wright et al. (2009b) showed that the direct effect of condensate evaporation in a climate model was to increase relative humidity by several per cent. They point out that there may have been too much ice to sublimate in their model. However, even small changes in the relative humidity matter for the radiation as will be shown in the following section.

\section{How large an effect could a few percent increase in the upper tropospheric relative humidity have on radiation?}

Shine and Sinha (1991) estimated the radiative forcing associated with increases of humidity. They increased water vapor mixing ratio by $10 \%$ in layers of $50 \mathrm{hPa}$ depth at different 
altitudes. The original humidity was taken from Manabe and Wetherald (1967). The relative humidity change that the $10 \%$ increase in water vapor mixing ratio corresponds to is shown in Fig. 3. The relative humidity change increases from $1.4 \%$ at $200 \mathrm{hPa}$ to $3.7 \%$ at $500 \mathrm{hPa}$, the mean value being about $2.6 \%$. We want to stress that for radiation, relative changes matter more than absolute changes.

We assume that relative humidity increases from $175 \mathrm{hPa}$ to $525 \mathrm{hPa}$ according to Fig. 3 and calculate the resulting change in the net infrared flux at the tropopause by summing the effect of individual perturbations in Fig. 3 of Shine and Sinha (summing up the effect from different layers will result in an error of about $10 \%$ according to Shine and Sinha). The corresponding decrease in the net infrared flux is about $0.9 \mathrm{~W} \mathrm{~m}^{-2}$ for the tropics, $0.8 \mathrm{~W} \mathrm{~m}^{-2}$ for summer midlatitudes and $0.5 \mathrm{~W} \mathrm{~m}^{-2}$ for winter midlatitudes. These results are for clear sky conditions but note that we use these calculations just to get a rough estimate for the magnitude of the effect.

Rather similar values for the changes in the outgoing longwave radiation due to a relative humidity increase in the upper troposphere were obtained by Udelhofen and Hartmann (1995).

\section{Conclusions}

Ramanathan et al. (2001) suggested that the suppression of precipitation associated with increasing amounts of aerosols could be associated with an increase of upper tropospheric humidity and that this could counter some of the aerosol cooling effect. Interestingly, there is some evidence for such an effect of aerosols from biomass burning and other sources on the observed positive moisture trend in the stratosphere (e.g. Sherwood, 2002; Notholt et al., 2005). The effects of aerosols on clouds properties that could lead to moistening in the upper troposphere can be seen in the recent spectral microphysics cloud model simulations by Khain et al. (2005, 2008). We argue that even in the absence of changes in net precipitation, i.e. no mean suppression of precipitation, aerosols can affect upper tropospheric humidity. Based on the results of Shine and Sinha (1991), we estimate that a $2-3 \%$ increase in relative humidity from 175 to $525 \mathrm{hPa}$ could change the net infrared flux at the tropopause by about $0.8 \mathrm{~W} \mathrm{~m}^{-2}$. Note that since no GCM explicitly parameterizes aerosol effects on convective clouds (Quaas et al., 2009), this effect cannot be seen in GCMs.

Unfortunately, reliable observations of humidity in the upper troposphere from the time anthropogenic aerosols were increasing most rapidly (1940-1980) are lacking, due to problems of radiosonde data and lack of satellite data before 1979. However, satellite data on upper tropospheric relative humidity after 1979 (McCarthy and Toumi, 2004) are consistent with the hypothesis that changes in the amounts of anthropogenic aerosols, smoke aerosols from biomass burn-

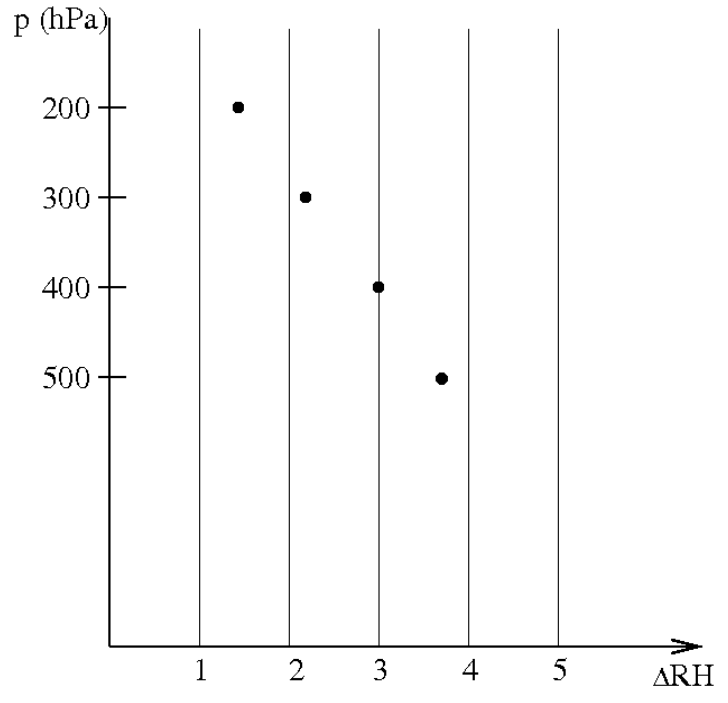

Fig. 3. Relative humidity increase in the upper troposphere corresponding to increasing water vapor mixing ratio from Manabe and Wetherald (1967) by $10 \%$ as in Shine and Sinha (1991).

ing and desert dust can have affected upper tropospheric relative humidity between 1979 and 1997 . We have summarized schematically the trends in global sulfur emissions and UTRH (from McCarthy and Toumi, 2004) in Fig. 2. There has been a decrease in UTRH in midlatitudes when sulfur emissions were decreasing (global emissions decreased from about 71 to about $58 \mathrm{TgS}$ between 1979 and 1997 according to Stern, 2006). The decrease of UTRH is stronger in the SH than in the NH. This could be due to the logarithmic sensitivity of clouds to $\mathrm{CCN}$ and more pristine conditions in the $\mathrm{SH}$ than in the NH. However, it is also possible that other sources of aerosols or unknown changes in the atmospheric circulation in the $\mathrm{NH}$ could be the reason. Also, if the large increase over the boreal regions of Asia is due to problems in data at higher latitudes, then the real difference between trends in $\mathrm{NH}$ and $\mathrm{SH}$ midlatitudes would be smaller.

The large positive trend of UTRH in the tropics $\left(10^{\circ} \mathrm{S}-\right.$ $10^{\circ} \mathrm{N}$; Fig. 2) has a large contribution from positive trends in the vicinity of equatorial Africa and over South America and occurred mainly during 1983-1989, when biomass burning was increasing in South America and when the dust levels of West Africa were anomalously high (Nicholson, 2000; Mahowald et al., 2007). Both the location and the timing suggest that aerosols may be the culprit for the increase of UTRH in the Tropics.

Observed global cloudiness changes, with less upper tropospheric cloudiness in the 1990s than in the 1980s, also support the hypothesis that aerosols may have affected microphysics in a way to increase the total water amount in the upper troposphere. Satellite data from over the North Atlantic ocean suggest that polluted clouds develop more extensive ice anvils than clean clouds (Koren et al., 2005). 
Satellite data also suggest that UTRH increases linearly with the amount of upper level cloud (Udelhofen and Hartmann, 1995). Changes in cloudiness may be one reason for the observed dimming before 1990 and brightening thereafter. The effect of upper tropospheric cloud changes on the net radiation depends on cloud optical depth and cloud top height (Fu et al., 2002) and other properties of the clouds. However, an increase in UTRH associated with increased aerosol amounts would have decreased the outgoing longwave radiation.

We conclude that the large increase of anthropogenic aerosols in the 20th century may have increased global UTRH and thereby decreased outgoing longwave radiation during most of the 20th century. The changes in UTRH during 18 yr (1979-1997) were about $1-2 \%$ in the midlatitudes. If the observed decrease of UTRH in midlatitudes were indeed associated with the decrease of sulfur emissions in 1979-1997, then larger absolute changes in UTRH may have occurred in the 20th century when sulfur emissions increased from about $10 \mathrm{Tg} \mathrm{S}$ to about $70 \mathrm{Tg} \mathrm{S}$ (Stern, 2006). However, careful analysis of data is needed to see whether this is indeed the case.

To learn more about the effect of anthropogenic aerosols on UTRH, both numerical simulations and observational studies are needed. We plan to use satellite data to evaluate relationships between anthropogenic aerosols, upper tropospheric clouds and UTRH. Allan et al. (2010) have shown how sensitive observed precipitation trends are to data set employed and how inter-comparisons of different data set products are needed. Caution is also required in using UTRH data sets. For example, the data set used by McCarthy and Toumi was affected by the clear-sky bias. Therefore, comparison with other data sets is required to verify or to rule out the proposed effect.

Ultimately, numerical simulations of radiative-convective equilibrium are needed to obtain an estimate of the global effect of anthropogenic aerosols on UTRH. A good representation of convection, which can account for convection's growth into mesoscale (for example the cloud-resolving convection parameterization of Grabowski, 2003), as well as a good microphysics scheme are needed to achieve this goal.

Acknowledgements. We thank Jouni Räisänen for useful discussions and two anonymous referees and the editor, Radovan Krejci for comments and questions that significantly improved the paper.

Edited by: R. Krejci

\section{References}

Allan, R. P., Soden, B. J., John, V. O., Ingram, W., and Good, P.: Current changes in tropical precipitation, Environ. Res. Lett., 5, 025205, doi:10.1088/1748-9326/5/2/025205, 2010.

Andreae, M. O.: Climatic effects of changing atmospheric aerosol levels, in: World Survey of Climatology, vol. 16, Future Climates of the World, edited by: A. Henderson-Sellers, Elsevier, New York, 341-392, 1995.
Bates, J. J. and Jackson, D. L.: Trends in upper-tropospheric humidity, Geophys. Res. Lett, 28, 1695-1698, 2001.

Bates, J. J., Jackson, D. L., Bréon, F.-M., and Bergen, Z. D.: Variability of tropical upper tropospheric humidity 1979-1998, J. Geophys. Res., 106, 32271-32281, 2001.

Cau, P., Methven, J., and Hoskins, B.: Origins of dry air in the tropics and subtropics, J. Climate, 20, 2745-2759, 2007.

Dessler, A. E. and Minschwaner, K.: An analysis of the regulation of tropical tropospheric water vapor, J. Geophys. Res., 112, D10120, doi:10.1029/2006JD007683, 2007.

Dessler, A. E. and Sherwood, C: Simulations of tropical upper tropospheric humidity, J. Geophys. Res., 105, 20155-20163, 2000.

Duncan, B. N., Randall, V. M., Staudt, A. C., Yevich, R., and Logan, J. A.: Interannual and seasonal variability of biomass burning emissions constrained by satellite observations, J. Geophys. Res., 108, 4100, doi:10.1029/2002JD002378, 2003.

Ekman, A. M. L., Engström, A., and Wang, C.: The effect of aerosol composition and concentration on the development and anvil properties of a continental deep convective cloud, Q. J. Roy. Meteorol. Soc., 133, 1439-1452, 2007.

Elliott, W. P. and Gaffen, D. J.: On the utility of radiosonde humidity archives for climate studies, B. Am. Meteorol. Soc., 72, 1507-1520, 1991.

Folkins, I., Kelly, K. K., and Weinstock, E. M.: A simple explanation for the increase in relative humidity between 11 and $14 \mathrm{~km}$ in the tropics, J. Geophys. Res., 107(D23), 4736, doi:10.1029/2002JD002185, 2002.

Fridlind, A. M., Ackerman, A. S., Jensen, E. J., Heymsfiled, A. J., Poellot, M. R., Stevens, D. E., Wang, D., Miloshevich, L. M., Baumgardner, D., Lawson, R. P., Wilson, J. C., Flagan, R. C., Seinfeld, J. H., Jonsson, H. H., VanReken, T. M., Varutbangkul, V., and Rissman, T. A.: Evidence for the predominance of midtropospheric aerosols as subtropical anvil cloud nuclei, Science, 304(5671), 718-722, doi:10.1126/science.1094947, 2004.

Fu, Q., Baker, M., and Hartmann, D. L.: Tropical cirrus and water vapor: an effective Earth infrared iris feedback?, Atmos. Chem. Phys., 2, 31-37, doi:10.5194/acp-2-31-2002, 2002.

Grabowski, W. W.: Impact of cloud microphysics on convectiveradiative quasi equilibrium revealed by cloud-resolving convection parameterization, J. Climate, 16, 3463-3475, 2003.

Held, I. M. and Soden, B. J.: Robust responses of the hydrological cycle to global warming, J. Climate, 19, 5686-5699, 2006.

Hong, Y., Kummerow, C. D., and Olson, W. S.: Separation of convective and stratiform precipitation using microwave brightness temperature, J. Appl. Meteorol., 38, 1195-1213, 1999.

Johanson, C. M. and Fu, Q.: Hadley cell widening: Model simulations versus observations, J. Climate, 22, 2713-2725, 2009.

John, V. O. and Buehler, S. A.: Comparison of microwave satellite humidity data and radiosonde profiles: A survey of European stations, Atmos. Chem. Phys., 5, 1843-1853, doi:10.5194/acp5-1843-2005, 2005.

Johnson, N. C. and Xie, S.-P.: Changes in the sea surface temperature threshold for tropical convection, Nature Geosci., 3, 842845, doi:10.1038/NGEO1008, 2010.

Khain, A. P. and Pokrovsky, A: Simulation of effects of atmospheric aerosols on deep turbulent convective clouds using a spectral microphysics mixed-phase cumulus cloud model. Part II: Sensitivity study, J. Atmos. Sci., 61, 2983-3001, 2004.

Khain, A. P., Rosenfeld, D., and Pokrovsky A.: Aerosol impact on 
the dynamics and microphysics of deep convective clouds, Q. J. Roy. Meteorol. Soc., 131, 2639-2663, 2005.

Khain, A. P., BenMoshe, N., and Pokrovsky, A.: Factors determining the impact of aerosols on surface precipitation from clouds: An attempt at classification, J. Atmos. Sci, 65, 1721-1748, 2008.

Kishcha, P., Starobinets, B., and Alpert, P.: Latitudinal variations of cloud and aerosol optical thickness trends based on MODIS satellite data, Geophys. Res. Lett., 34, L05810, doi:10.1029/2006GL028796, 2007.

Knippertz, P. and Wernli, H.: A lagrangian climatology of tropical moisture exports to the Northern Hemispheric extratropics, J. Climate, 23, 987-1003, doi:10.1175/2009JCLI3333.1, 2010.

Knutson, T. R. and Manabe, S.: Time-mean response over the tropical Pacific to increased $\mathrm{CO} 2$ in a coupled ocean-atmosphere model, J. Climate, 8, 2181-2199, 1995.

Koren, I., Kaufman, Y. J., Rosenfeld, D., Remer, L. A., and Rudich, Y.: Aerosol invigoration and restructuring of Atlantic convective clouds, Geophys. Res. Lett., 32, L14828, doi:10.1029/2005GL023187, 2005.

Koren, I., Remer, L. A., and Longo, K.: Reversal of trend of biomass burning in the Amazon, Geophys. Res. Lett., 34, L20404, doi:10.1029/2007GL031530, 2007.

Koren, I., Martins, J. V., Remer, L. A., and Afargan, H.: Smoke invigoration versus inhibition of clouds over the Amazon, Science, 321, 946-949, 2008.

Lu, J., Vecchi, G. A., and Reichler, T.: Expansion of the Hadley cell under global warming, Geophys. Res. Lett., 34, L06805, doi:10.1029/2006GL028443, 2007.

Mahowald, N. M., Ballantine, J. A., Feddema, J., and Ramankutty, N.: Global trends in visibility: implications for dust sources, Atmos. Chem. Phys., 7, 3309-3339, doi:10.5194/acp-7-3309-2007, 2007.

Manabe, S. and Wetherald, R. T.: Thermal equilibrium of the atmosphere with a given distribution of relative humidity, J. Atmos. Sci., 24, 241-259, 1967.

May, P. T., Allen, G., Vaughan, G., and Connolly, P.: Aerosol and thermodynamic effects on tropical cloud systems during TWPICE and ACTIVE, Atmos. Chem. Phys., 9, 15-24, doi:10.5194/acp-9-15-2009, 2009.

McCarthy, M. P. and Toumi, R..: Observed interannual variability of tropical tropospheric relative humidity, J. Climate, 17, 31813191, 2004.

Mieville, A., Granier, C., Liousse, C., Guillame, B., Mouillot, F., Lamarque, J.-F., Grégoire, and J.-M., and Pétron, G.: Emissions of gases and particles from biomass burning during the 20th century using satellite data and an historical reconstruction, Atmos. Environ., 44, 1469-1477, 2010.

Mishchenko, M., Geogdzhayev, I. V., Rossow, W. B., Cairns, B., Carlson, B. E., Lacis, A. A., Liu, L., and Travis, L. D.: Longterm satellite record reveals likely recent aerosol trend, Science, 315, p. 1543, 2007.

Nicholson, S.: Land surface processes and Sahel climate, Rev. Geophys., 38, 117-139, 2000.

Notholt, J., Luo, B. P., Fueglistaler, S., Weisernstein, D., Rex, M., Lawrence, M. G., Bingemer, H., Wohltmann, I., Corti, T., Warneke, T., von Kuhlmann, R., and Peter, T.: Influence of tropospheric SO2 emissions on particle formation and the stratospheric humidity, Geophys. Res. Lett., 32, L07810, doi:10.1029/2004GL022159, 2005.
Pierrehumbert, R. T. and Roca, R.: Evidence for control of Atlantic subtropical humidity by large scale advection, Geophys. Res. Lett., 25, 4537-4540, 1998.

Prins, E. M. and Menzel, W. P.: Trends in South American biomass burning detected with the GOES visible infrared spin scan radiometer atmosphere sounder from 1983 to 1991, J. Geophys. Res., 99(D8), 16719-16735, 1994.

Quaas, J., Ming, Y., Menon, S., Takemura, T., Wang, M., Penner, J. E., Gettelman, A., Lohmann, U., Bellouin, N., Boucher, O., Sayer, A. M., Thomas, G. E., McComiskey, A., Feingold, G., Hoose, C., Kristjánsson, J. E., Liu, X., Balkanski, Y., Donner, L. J., Ginoux, P. A., Stier, P., Grandey, B., Feichter, J., Sednev, I., Bauer, S. E., Koch, D., Grainger, R. G., Kirkevåg, A., Iversen, T., Seland, Ø., Easter, R., Ghan, S. J., Rasch, P. J., Morrison, H., Lamarque, J.-F., Iacono, M. J., Kinne, S., and Schulz, M.: Aerosol indirect effects - general circulation model intercomparison and evaluation with satellite data, Atmos. Chem. Phys., 9, 8697-8717, doi:10.5194/acp-9-8697-2009, 2009.

Ramanathan, V., Crutzen, P. J., Kiehl, J. T., and Rosenfeld, D.: Aerosols, climate and the hydrological cycle, Science, 294, 2119-2124, 2001.

Rosenfeld, D., Rudich, Y., and Lahav, R.: Desert dust suppressing precipitation: A possible desertification feedback loop, P. Natl Acad. Sci. USA, 98, 5975-5980, 2001.

Rosenfeld, D., Lohmann, U., Raga, G. B., O’Dowd, C. D., Kulmala, M., Fuzzi, S., Reissell, A., and Andreae, M. O.: Flood or drought: How do aerosols affect precipitation? Science, 321 , 1309-1313, 2008.

Salathe, E. P. and Hartmann, D. L.: A trajectory analysis of tropical upper-tropospheric moisture and convection, J. Climate, 10, 2533-2547, 1997.

Saji, N. H., Goswami, B. N., Vinayachandran, P. N., and Yamagata, T.: A dipole mode in the tropical Indian Ocean, Nature, 401, 360-363, 1999.

Seidel, D. J., Fu, Q., Randel W. J., and Reichler, T. J.: Widening of the tropical belt in a changing climate, Nat. Geosci., 1, 21-24, 2008.

Sherwood, S.: A microphysical connection among biomass burning, cumulus clouds, and stratospheric moisture, Science, 295, 1272-1275, 2002

Sherwood, S. C., Roca, R., Weckwerth, T. M., and Andronova, N. G.: Tropospheric water vapor, convection, and climate, Rev. Geophys., 48, RG2001, doi:10.1029/2009RG000301, 2010.

Shine, K. P. and Sinha, A.: Sensitivity of the Earth's climate to height-dependent changes in the water vapor mixing ratio, $\mathrm{Na}$ ture, 354, 382-384, 1991.

Smith, S. J., Conception, E., Andres, R., and Lurz, J.: Historical Sulfur Dioxide Emissions 1850-2000: Methods and Results, PNNL Research Report, PNNL-14537, 2004.

Soden, B. J.: The impact of tropical convection and cirrus on upper troposphere humidity: A Lagrangian analysis of satellite measurements, Geophys. Res. Lett., 31, L20104, doi:10.1029/2004GL020980, 2004.

Soden, B. J., Jackson, D. L., Ramaswamy, V., Schwarzkopf, M. D., and Huang, X.: The radiative signature of upper tropospheric moistening, Science, 310, 841-844, 2005.

Stern, D. I.: Reversal of the trend in global anthropogenic sulfur emissions, Glob. Environ. Change, 16, 207-220, 2006.

Streets, D. G., Wu, Y., and Chin, M.: Two-decadal 
aerosol trends as a likely explanation of the global dimming/brightening transition, Geophys. Res. Lett., 33, L15806, doi:10.1029/2006GL026471, 2006.

Treffeisen, R., Krejci, R., Ström, J., Engvall, A. C., Herber, A., and Thomason, L.: Humidity observations in the Arctic troposphere over Ny-Ålesund, Svalbard based on 15 years of radiosonde data, Atmos. Chem. Phys., 7, 2721-2732, doi:10.5194/acp-7-27212007, 2007.

Trenberth, K. E., Jones, P. D., Ambenje, B., Bojariu, R., Easterling, D., Klein Tank, A., Parker, D., Rahimzadeh, F., Renwick, J. A., Rusticucci, M., Soden, B., and Zhai, P.: Observations: Surface and Atmospheric Climate Change, in: Climate Change 2007: The Physical Science Basis. Contribution of Working Group I to the Fourth Assessment Report of the Intergovernmental Panel on Climate Change, edited by: Solomon, S., Qin, D., Manning, M., Chen, Z., Marquis, M., Averyt, K. B., Tignor, M., and Miller, H. L., Cambridge University Press, Cambridge, United Kingdom and New York, NY, USA, 2007.

Udelhofen, P. M. and Hartmann, D. L.: Influence of tropical cloud systems on the relative humidity in the upper troposphere, J. Geophys. Res., 100, 7423-7440, 1995.
Vecchi, G. A., Soden, B. J., Wittenberg, A. T., Held, I. M., Leetmaa, A., and Harrison, M. J.: Weakening of tropical Pacific atmospheric circulation due to anthropogenic forcing, Nature, 441, 73-76, doi:10.1038/nature04744, 2006.

Wild, M.: Global dimming and brightening: A review, J. Geophys. Res., 114, D00D16, doi:10.1029/2008JD011470, 2009.

Wright, J. S., Fu, R., and Heymsfield, A. J.: A statistical analysis of the influence of deep convection on water vapor variability in the tropical upper troposphere, Atmos. Chem. Phys., 9, 5847-5864, doi:10.5194/acp-9-5847-2009, 2009a.

Wright, J. S., Sobel, A. H., and Schmidt, G. A.: Influence of condensate evaporation on water vapor and its stable isotopes in a GCM, Geophys. Res. Lett., 36, L12804, doi:10.1029/2009GL038091, 2009b.

Zhang, R., Li, G., Fan, J., Wu, D. L., and Molina, M. J.: Intensification of Pacific storm track linked to Asian pollution, P. Natl. Acad. Sci. USA, 104, 5295-5299, 2007. 